\title{
Effect of thermal sludge processing on selected components of air quality in the vicinity of a wastewater treatment plant
}

\author{
Robert Cichowicz $^{1}{ }^{\mathbb{D}} \cdot$ Artur Stelęgowski $^{1}$
}

Received: 17 April 2018 / Accepted: 9 November 2018 / Published online: 19 November 2018

(c) The Author(s) 2018

\begin{abstract}
Wastewater treatment plants (WWTPs) generate considerable amounts of sewage sludge. The thermal sludge treatment system (TSTS) is therefore one of the most important technological units of a WWTP. However, due to technological processes involved in thermal sludge treatment, specific chemical, physical and biological conditions may arise that can affect air quality both within the WWTP area and in its vicinity. This study uses data from experimental measurements taken in and around a WWTP to assess the impact of thermal sludge treatment on air quality. The selected facility is located in the Group Sewage Treatment Plant in the Lodz Agglomeration and serves a population of around one million. The concentrations of harmful gaseous substances, bacteria, fungi, particulate matter and thermal energy were investigated. The qualitative and quantitative characteristics of physical, chemical, and biological factors and their influence on air quality are presented.
\end{abstract}

Keywords Air quality $\cdot$ Particulate matter $\cdot$ Thermal energy $\cdot$ Bacteria and fungi

\section{Introduction}

Incineration processes are carried out in remotely controlled central and local heating systems. The use of fossil fuels and biomass can cause the emission of considerable amounts of harmful air pollutants into the environment (Cichowicz 2018; Cichowicz et al. 2017, 2016). However, municipal waste is a specific type of fuel, due to the presence of undesirable substances. Therefore, waste is incinerated in specially designed industrial systems. Thermal sludge treatment systems (TSTSs) have become an important element in large wastewater treatment plants (WWTPs). The increasing number of such systems in Poland and Europe is a testament to the high efficiency of TSTS (Pająk 2013).

The parameters of sewage sludge utilized in TSTS vary depending on the method of pre-treatment, which may be aerobic or anaerobic. Anaerobic digestion produces, among

This work was presented at the 44th International Conference of Slovak Society of Chemical Engineering held in Tatranské Matliare on May 21-25, 2018.

Robert Cichowicz

robert.cichowicz@p.lodz.pl

1 Faculty of Architecture, Civil and Environmental Engineering, Lodz University of Technology, al. Politechniki 6, 90-924 Łódź, Poland others, biogas consisting of methane and carbon dioxide, while aerobic digestion produces carbon dioxide and ammonia (Arthurson 2008). Both aerobic and anaerobic digestion processes, biologically stabilize and reduce the volume of sludge, but also reduce the organic content and decreases its heating value by up to $50 \%$ (Fytili and Zabaniotou 2008). Decreasing the heating value is undesirable, since sewage sludge contains a significant amount of moisture, normally in the range of 72-98\% (Bianchini et al. 2015), and requires thermal energy and dewatering for drying. Sewage sludge also contains significant amounts of nitrogen, heavy metals (Dai et al. 2007; Panepinto and Genon 2014), bacteria and other pathogens (Strauch 1991; Arthurson 2008). Neither aerobic nor anaerobic treatment provides sufficient sanitization (Arthurson 2008).

Thermal sludge treatment enables a large reduction in the volume of sewage sludge (by up to $90 \%$ ), the destruction of organic compounds, the minimization of odors and the recovery of energy. However, the sludge delivered for incineration should first be dried. The drying process decreases the water content in sewage sludge, but also (depending on the drying temperature, residence time and other parameters) causes the release of amines, volatile organic and sulfurcontaining compounds and odor (Ding et al. 2015). The incineration of sewage sludge results in the emission, inter alia, of heavy metals, dust, $\mathrm{NO}_{\mathrm{x}}, \mathrm{SO}_{2}, \mathrm{HCl}$, and $\mathrm{HF}$ (Fytili 
and Zabaniotou 2008). By applying the flue gas cleaning process, emission levels can be reduced by up to $50 \%$ for $\mathrm{NO}_{\mathrm{x}}$, over $95 \%$ for most heavy metals and by up to $99.9 \%$ for dust (Svoboda et al. 2016), depending on the dust filtration technology.

A specific system is required to reduce of the level of $\mathrm{NO}_{\mathrm{x}}$ in flue gas. The two main systems available are based on Selective Non-Catalytic Reduction (SNCR) and Selective Catalytic Reduction (SCR). In the SNCR method, ammonia or urea is used at temperatures from 870 to $1260{ }^{\circ} \mathrm{C}$. In the SCR method, ammonia is used in the presence of catalysts at temperatures from 260 to $540{ }^{\circ} \mathrm{C}$ (Shah et al. 1999). The incineration of wet sewage sludge, which contains a large amount of water (70-80\% wt), results in very low emission of $\mathrm{NO}_{\mathrm{x}}$ (Werther et al. 1995; Werther and Ogada 1999). However, ammonia emissions from anaerobically digested, pre-dried sewage sludge can be very high, up to $1.6 \mathrm{mg} \mathrm{g}^{-1}$ d.m. (Wielgosiński et al. 2016), depending on the combustion temperature. Special attention should also be paid to the efficiency of mercury removal in the dry flue gas cleaning process, which can attain 80-95\% (Svoboda et al. 2016). However, due to the limitations of cleaning installations, some pollutants always penetrate into the environment.

The formation of problematic and hazardous chemical substances, bacteria and fungi during the storage, drying and incineration of sewage sludge can put people in danger and cause discomfort (Cichowicz and Stelęgowski 2018a, 2018b; Fytili and Zabaniotou 2008; Wielgosiński et al. 2016). Therefore, when planning the location of waste incineration plants, authorities should consider not only the technical and technological aspects but also the opinions of local communities. Public opinion is usually negative, due to widespread concerns relating to air quality and the amount of pollution in the vicinity of WWTP (Wielgosiński 2016).

The research literature on this topic mostly concerns the way WWTP personnel are affected by compounds such as dioxins (PCDD/F), polycyclic aromatic hydrocarbons (TCDD) and heavy metals $(\mathrm{Cr}, \mathrm{Cd}, \mathrm{Ni}, \mathrm{Pb})$, which form during the normal operation of municipal waste incineration systems (Carmen et al. 2003; Shih et al. 2006). Articles on existing TSTSs in WWTPs for the most part analyze the efficiency of air treatment processes and the concentrations of pollutants in the exhaust gas (Pohorely et al. 2005; Panepinto and Genon 2014; Lu et al. 2013) or emissions from sludge drying (Ding et al. 2015). The objective of our study was to investigate the influence (significant, minor or none) of a TSTS on air quality in the near vicinity of a large WWTP (serving a population of around one million).

\section{Experimental}

The selected TSTS is located in the Group Sewage Treatment Plant of Lodz (GOŚ- $-\mathrm{EAM}$ ), in central Poland in Europe. The plant covers an area of approximately 41.3 ha and receives sewage in quantities of around 150-195 thousand $\mathrm{m}^{3}$ day $^{-1}$. The sludge first undergoes an anaerobic procedure, producing biogas. After digestion (Table 1), most of the sludge is thermally treated (50-80\%) and a small part is composted. The capacity of the TSTS is about $54 \mathrm{Mg}$ d.m. day ${ }^{-1}$ (dry matter of sewage sludge). This amounts to around $18,000 \mathrm{Mg}$ d.m. year ${ }^{-1}$. The analyzed TSTS includes two independent technological lines (I and II), consisting of a storage subsystem, transportation and pre-drying of sludge. The elements of the TSTS include, among others, a fluidized-bed furnace, a recuperator of heat from exhaust gases, a steam boiler, a multi-cyclone, a bag filter, an exhaust fan, a chimney, and a steam distribution subsystem. In 2013, 2015, and 2016, between around $2 \mathrm{Mg}$ and $10 \mathrm{Mg} \mathrm{day}^{-1}$ of the sludge was stored in the yard adjacent to the TSTS building.

After anaerobic treatment and mechanical dewatering, the sewage sludge is transported by screw conveyors to two $50 \mathrm{~m}^{3}$ storage silos/tanks. Part of the sludge (around $20 \mathrm{~m}^{3}$ ) was stored temporarily outside the TSTS building, in an adjacent area. The sludge is pumped to disc dryers inside the building, which pre-dry the material from around 20-24\% to $30-32 \%$ dry matter. The energy for pre-drying, produced using saturated water vapor, is recovered from the incineration of sludge. Pre-dried sludge is thermally transformed (gasified) at a temperature of approximately $850{ }^{\circ} \mathrm{C}$ for at least $2 \mathrm{~s}$. The sludge is gasified and incinerated in a fluidized bed furnace using "Pyrofluid" technology. For this purpose, two "Pyrofluid" fluidized bed furnaces by Veolia Water
Table 1 Composition of sewage sludge before drying (Wielgosiński et al. 2014)

\begin{tabular}{lclr}
\hline Composition of sludge & Average value & Composition of sludge & Average value \\
\hline $\mathrm{pH} /(-)$ & 7.57 & $\mathrm{~S} /(\% \mathrm{~d} . \mathrm{m})$. & 1.35 \\
Dry matter/(\%) & 22.15 & $\mathrm{Cl} /(\% \mathrm{~d} . \mathrm{m})$. & 0.11 \\
Moisture/(\%) & 79.37 & $\mathrm{~Pb} /\left(\mathrm{mg} \mathrm{kg}^{-1} \mathrm{~d} . \mathrm{m}.\right)$ & 57.06 \\
Heating value/(MJ kg ${ }^{-1}$ d.m.) & 10.84 & $\mathrm{Cr} /\left(\mathrm{mg} \mathrm{kg}^{-1} \mathrm{~d} . \mathrm{m}.\right)$ & 207.55 \\
Organic matter/(\% d.m.) & 59.45 & $\mathrm{Zn} /\left(\mathrm{mg} \mathrm{kg}^{-1} \mathrm{~d} . \mathrm{m}.\right)$ & 1553.73 \\
Total nitrogen/(\% d.m.) & 4.48 & $\mathrm{Hg} /\left(\mathrm{mg} \mathrm{kg}^{-1} \mathrm{~d} . \mathrm{m}.\right)$ & 3.19 \\
Ammonia nitrogen/(\% d.m.) & 0.70 & $\mathrm{Cu} /\left(\mathrm{mg} \mathrm{kg}^{-1} \mathrm{~d} . \mathrm{m}.\right)$ & 413.49 \\
\hline
\end{tabular}


Technologies are operated in the TSTS. Each of these furnaces is characterized by power of about $3.95 \mathrm{MW}$ ("Pyrofluid" chamber, fluidized mixing, $4000-6000 \mathrm{~m}^{3} \mathrm{~h}^{-1}$ regime, $750-800{ }^{\circ} \mathrm{C}$ sand bed temperature). The exhaust gases are cleaned by employing a dry method, using activated coal and sodium bicarbonate. Sodium bicarbonate is applied in doses to achieve a value below $40 \mathrm{mg} \mathrm{Nm}^{-3}$ for $\mathrm{SO}_{2}$ and $9 \mathrm{mg} \mathrm{Nm}^{-3}$ for $\mathrm{HCl}$ in the flue gas. Since the incineration of anaerobically digested, pre-dried wet sewage sludge results in low emission of $\mathrm{NO}_{\mathrm{x}}$ (Werther et al. 1995), no $\mathrm{NO}_{\mathrm{x}}$ reduction system is applied. However, around $150-300 \mathrm{mg} \mathrm{m}^{-3}$ of activated carbon is injected to reduce the amount of mercury in the flue gas. Dedusting is performed in cyclones and filtration in bag filters. The dedusted and cleaned exhaust gases are directed into the atmosphere via two chimneys measuring $0.7 \mathrm{~m}$ in inner diameter and $25 \mathrm{~m}$ in height. The nominal temperature of the exhaust gases at the chimney outlet is $190{ }^{\circ} \mathrm{C}$ and the velocity is $14.16 \mathrm{~m} \mathrm{~s}^{-1}$. The oxygen concentration in the flue gases is around $9 \%$.

In this study, air quality was analyzed with respect to harmful factors such as the concentration of chemical substances $\left(\mathrm{CO}, \mathrm{CO}_{2}, \mathrm{NO}_{\mathrm{x}}, \mathrm{SO}_{2}, \mathrm{NH}_{3}, \mathrm{CH}_{4}, \mathrm{H}_{2} \mathrm{~S}\right)$, physical factors (dust, thermal energy) and biological agents (bacteria and fungi). Data from automatic measurements of TSTS emissions were used to model the concentration of air pollutants in WWTP area of 108 ha. The data used in the analysis were collected during quarterly experimental measurements of air quality carried out in the years 2012-2015 at 7 points located in the area of the Group Sewage Treatment Plant WWTP itself, and at 8 points in its near vicinity (Procyk and Helbig 2013; Horodecka and Helbig 2014; SGS EkoProjekt 2015; Skwarska and Horodecka 2016). An analysis was made of the interdependence between the concentration of air pollution in the vicinity of the TSTS (point number one in Fig. 1) and the "background" concentration in other locations. In 2016, additional measurements were performed for biological and physical factors within the TSTS building and in its close vicinity. The spread of pollution from the emitters was modeled using the OPA03 application (EkoSoft). The model was implemented with a grid of 11,000 receptors. As will be discussed later, the model could not be validated due to the low concentration of pollution caused by the TSTS relative to the total air pollution in the vicinity of the WWTP.

\section{Results and discussion}

The highest annual concentrations in the exhaust gases from technological lines I and II were observed for $\mathrm{SO}_{2}, \mathrm{NO}_{\mathrm{x}}$ and $\mathrm{NH}_{3}$ (Fig. 2). However, the average acceptable daily values for this type of system (according Directive 2010/75/EU) were exceeded on only four occasions, all of which were

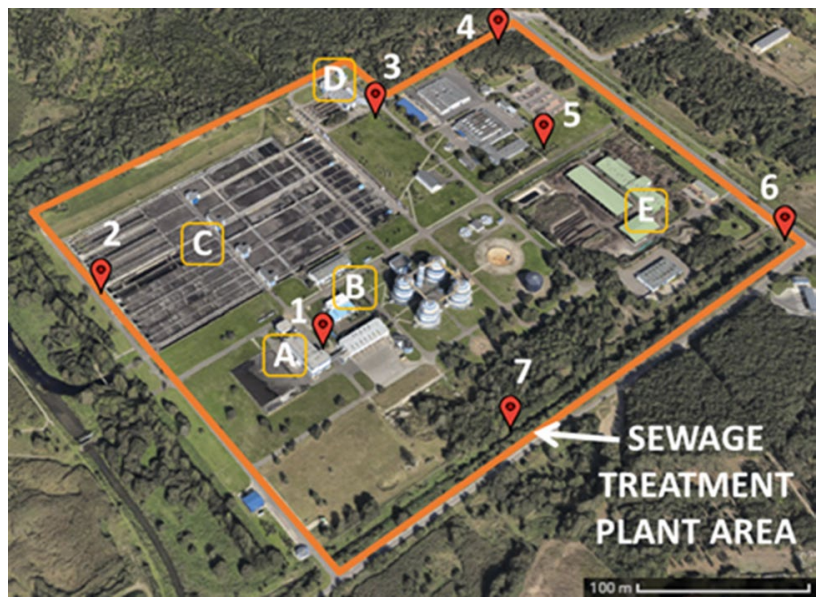

Fig. 1 Location of measurement points (1-7) in GOŚ-ŁAM, including the thermal sludge transformation system a, boiler and power plant $\mathbf{b}$, sludge chamber $\mathbf{c}$, inlet chamber and screen room $\mathbf{d}$ and the composting facility d Source: Google Maps

observed in 2012 and concerned $\mathrm{SO}_{2}$. However, low emissions of $\mathrm{NO}_{\mathrm{x}}$ and high emission of $\mathrm{NH}_{3}$ were associated with the incineration of anaerobically digested (Wielgosiński et al. 2016), pre-dried wet/semi-dry sewage sludge (Werther et al. 1995; Werther and Ogada 1999).

Both technological lines underwent various periods of downtime during the period of analysis. These periods totalled on average 121 days a year for line "I" and around 74 days a year for line "II". At the same time, no relationship was observed between the amounts of exhaust gases generated and the average daily temperature or wind speed (Fig. 3). Three basic phases were identified. In the first period, $9 \%$ of the year, no technological line was operational and no pollution was emitted. In the second period, $35 \%$ of the year, only one technological line was operational and the flow of exhaust gases was between 7000 and $11,000 \mathrm{Nm}^{3} \mathrm{~h}^{-1}$. In the third period, approximately $56 \%$ of the year, both technological lines were in operation and the flow of exhaust was approximately $15,000-20,000 \mathrm{Nm}^{3} \mathrm{~h}^{-1}$. As a consequence, the conditions associated with the emission of air pollution varied considerably.

Real average temperature conditions and the actual velocities of the exhaust gases were used in the model. The conditions for the first technological line were as follows: average temperature $172{ }^{\circ} \mathrm{C}$, velocity $12.14 \mathrm{~m} \mathrm{~s}^{-1}$. The average temperature was $167^{\circ} \mathrm{C}$ for the second line and the velocity was $13.66 \mathrm{~m} \mathrm{~s}^{-1}$. Only pollution associated with TSTS operation was analyzed using the model (Figs. 4, 5). The spatial distribution of air pollution connected to TSTS work showed that TST emission had a minor influence on air quality in the WWTP area. The share of the total concentration of pollution associated with TSTS emission did not exceed $0.30 \mu \mathrm{g} \mathrm{m}^{-3}$ for $\mathrm{NO}_{\mathrm{x}}, 0.80 \mu \mathrm{g} \mathrm{m}^{-3}$ for $\mathrm{SO}_{2}$, 


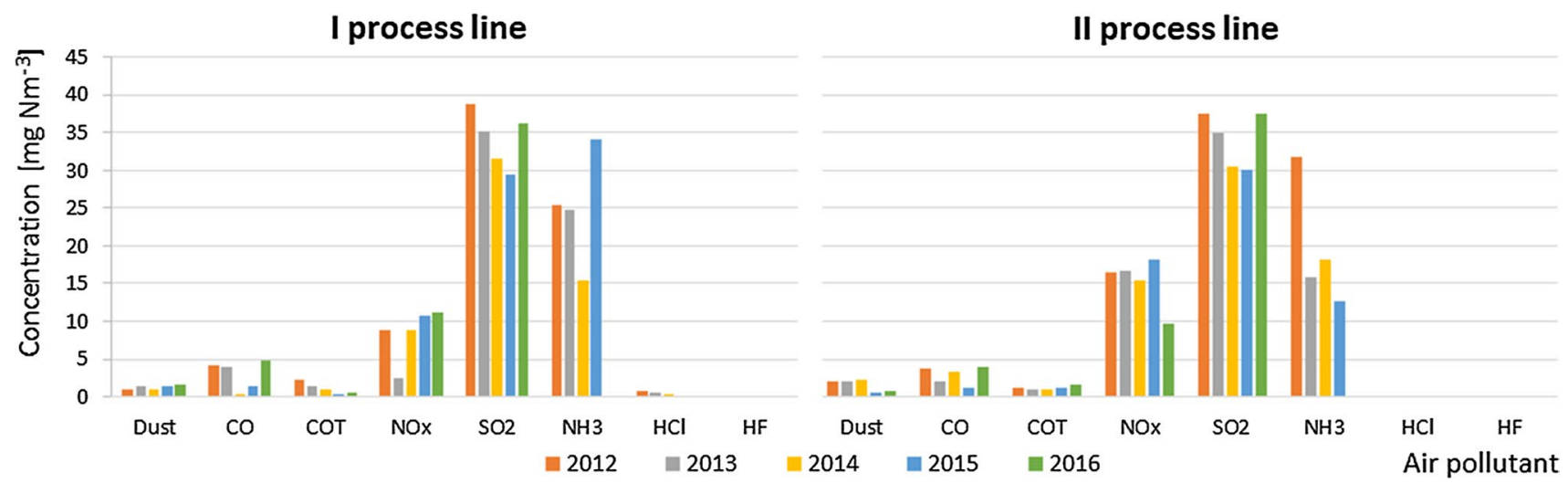

Fig. 2 Concentration of pollution in cleaned exhaust gases from technological lines I and II in 2012-2015 (11\% $\mathrm{O}_{2}$ concentration in flue gas volume)
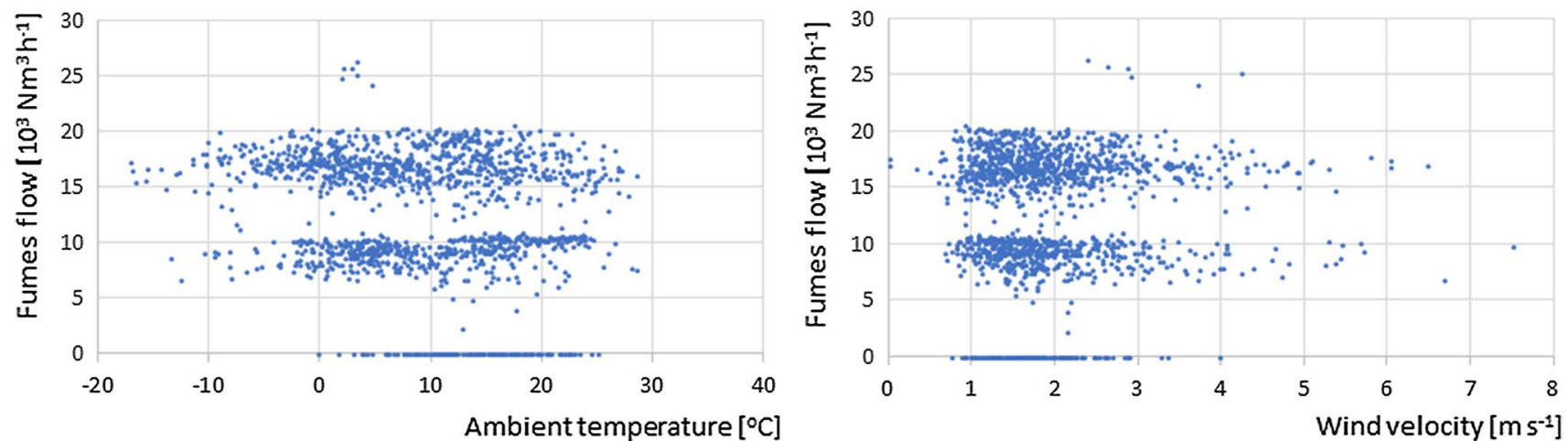

Fig. 3 Total flow of exhaust gases (lines "I" and "II") depending on average daily temperature and wind speed
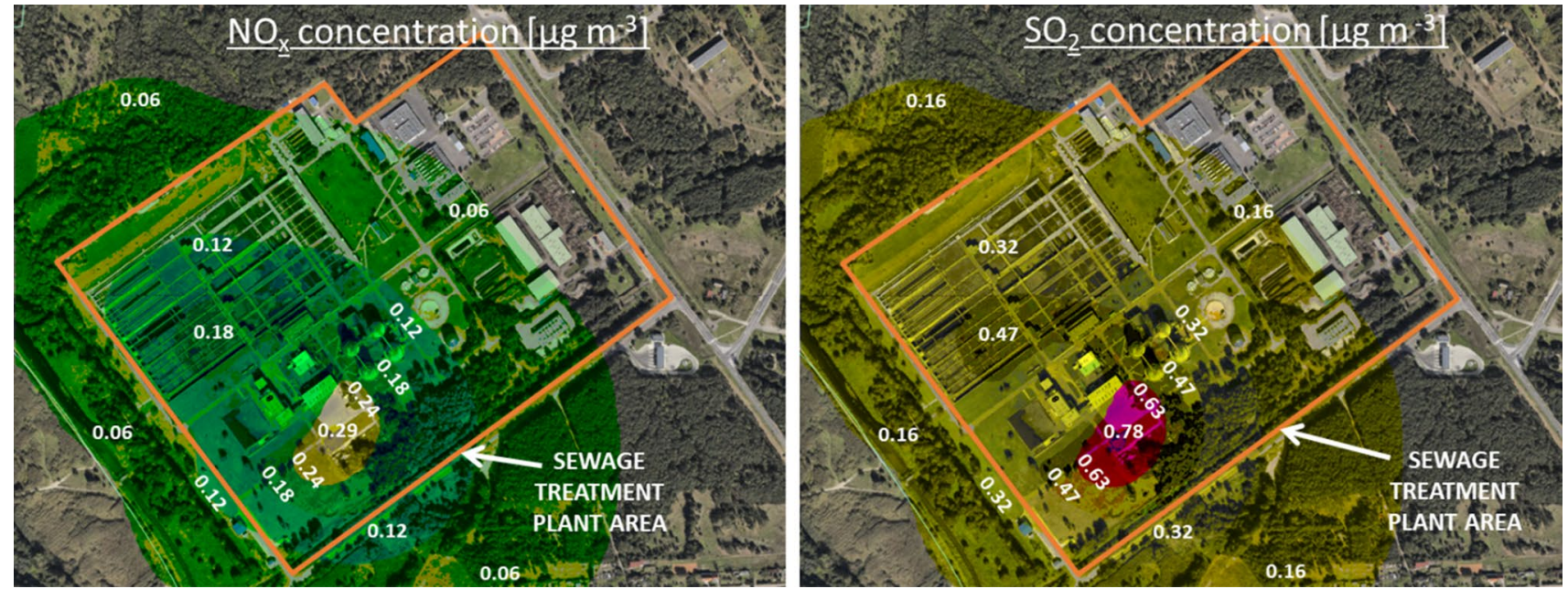

Fig. 4 Average annual concentration of $\mathrm{NO}_{\mathrm{x}}$ and $\mathrm{SO}_{2}$ emitted from the analyzed system

$0.020 \mu \mathrm{g} \mathrm{m}^{-3}$ for $\mathrm{PM}_{10}$ and $0.0070 \mu \mathrm{g} \mathrm{m}^{-3}$ for $\mathrm{HCl}$ (Figs. 4, 5). These values represent, respectively, 0.75, 4.00, 0.05, and $0.07 \%$ of the acceptable average annual concentrations for these substances (as determined in Directive 2008/50/ 

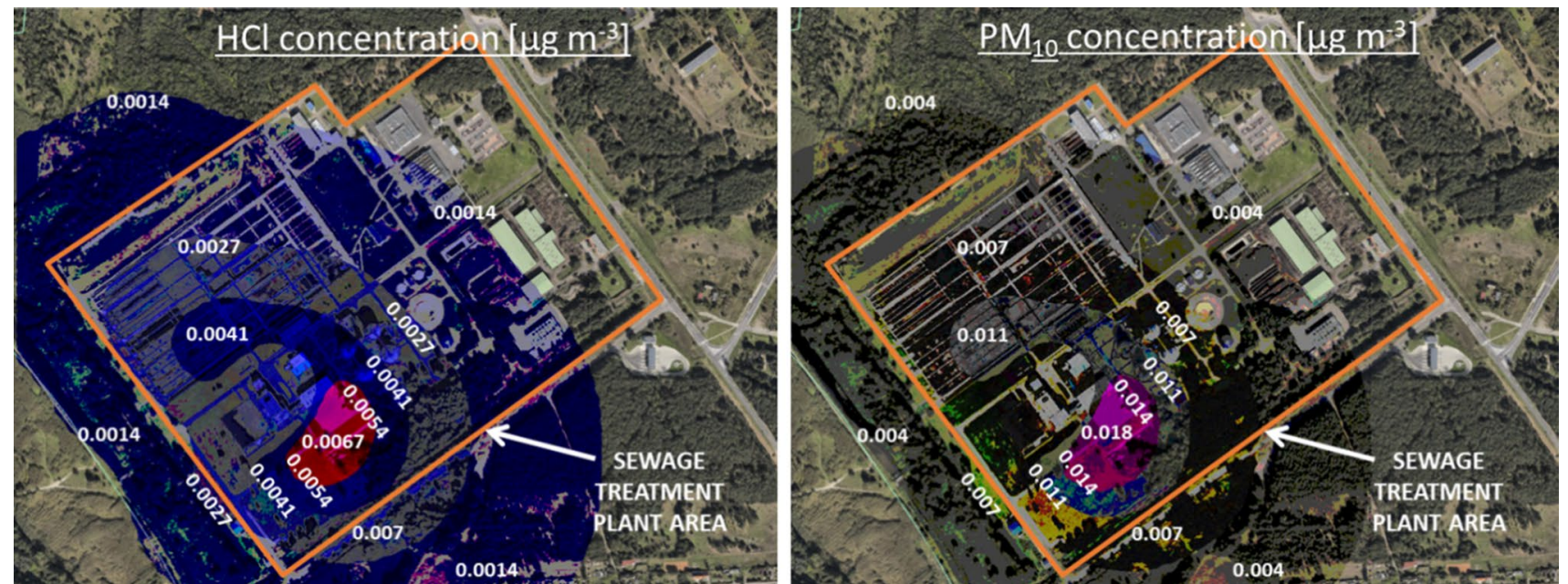

Fig. 5 Average annual concentration of $\mathrm{HCl}$ and $\mathrm{PM}_{10}$ emitted from the analyzed system

EC). However, it should be remembered that the average hourly concentrations of pollution could be much higher in the case of maximum hourly emission.

To analyze the influence of physical parameters on the spread of emitted pollutants, flue gas conditions in the model were changed from real to nominal values. Calculations were made for a nominal temperature of $190{ }^{\circ} \mathrm{C}$ and nominal flue gas velocity of $14.16 \mathrm{~m} \mathrm{~s}^{-1}$. The results of the numerical analysis with the nominal conditions did not differ significantly from those obtained with the real conditions. The highest annual concentration of air pollutants in the WWTP area decreased by only $0.02 \mu \mathrm{g} \mathrm{m}^{-3}$ for $\mathrm{NO}_{\mathrm{x}}$, by $0.05 \mu \mathrm{g} \mathrm{m}^{-3}$ for $\mathrm{SO}_{2}$, by $0.002 \mu \mathrm{g} \mathrm{m}^{-3}$ for $\mathrm{PM}_{10}$ and by $0.0005 \mu \mathrm{g} \mathrm{m}^{-3}$ for $\mathrm{HCl}$. Thus, in the analyzed case there was no significant difference between the actual and the nominal conditions of exhaust gas flow.
Based on experimental measurements, the location of the TSTS had no significant impact on the concentration of air pollutants in the WWTP area. The "TSTS/background ratio" was calculated by dividing the concentration of air pollutants near the TSTS building by the concentration of "background" pollution (Fig. 6). The level of air pollutants ( $\mathrm{CO}, \mathrm{CO}_{2}, \mathrm{NO}_{\mathrm{x}}, \mathrm{SO}_{2}, \mathrm{NH}_{3}, \mathrm{CH}_{4}, \mathrm{H}_{2} \mathrm{~S}$ ) in the vicinity of the TSTS was similar to the level of "background" pollution in the windward locations. These findings confirmed that only a low level of air pollution was caused by the TSTS, relative to the total concentration of pollutants in the air within the area of the WWTP. An exception was observed in the case of $\mathrm{NH}_{3}$, the concentration of which was 2.0-3.5 times higher in the proximity of TSTS than in the remaining measurement points. This was due to the high concentrations of $\mathrm{NH}_{3}$ near the TSTS in 2014, which were up to 8.6 times higher than the "background" concentration

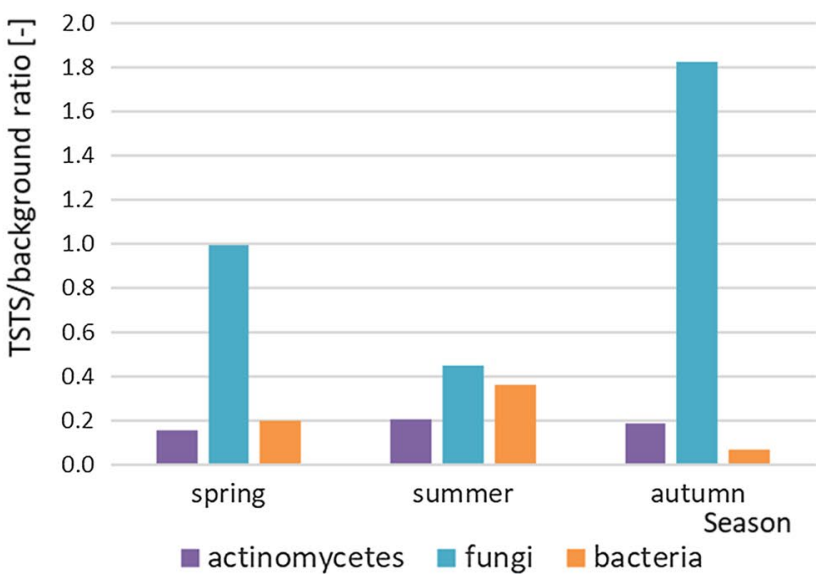

$\square$ actinomycetes fungi $\square$ bacteria

Fig. 6 Ratio of air pollutant concentration measured near the TSTS divided by the "background" pollution ("TSTS/background ratio")

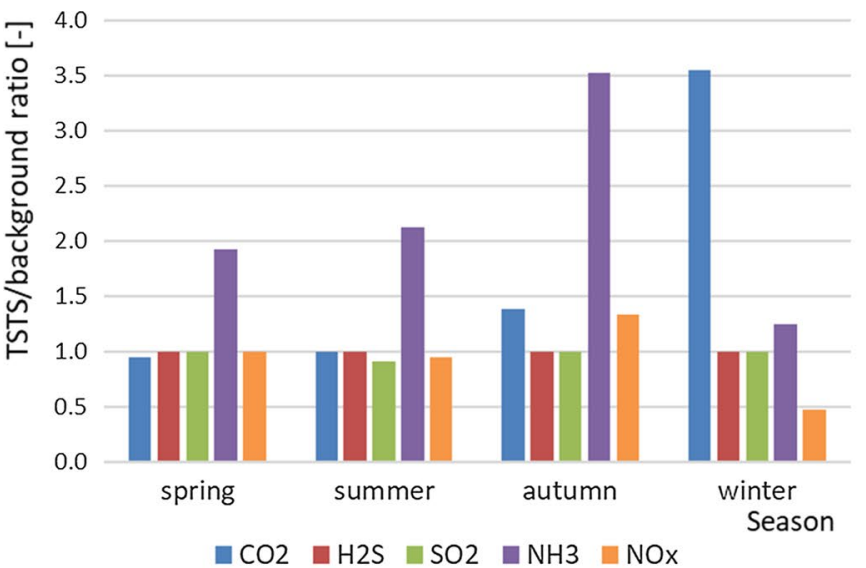


noted during measurements taken in November 2014. This finding is difficult to explain, especially given that the $\mathrm{NH}_{3}$ emissions from the TSTS chimneys did not change significantly. Therefore, the increased concentration of $\mathrm{NH}_{3}$ was probably caused by another technological unit of the WWTP, such as the composting facility.

Measurements performed during the winter revealed much higher concentrations of $\mathrm{CO}_{2}$ than during other times of year, despite the fact that the operation of the system did not vary depending on the season. This increase may have had its origin in another WWTP technological units, such as the sludge chamber or composting plant (Fig. 1). The concentration of $\mathrm{CH}_{4}$ varied depending on the date of measurement, and near the TSTS it ranged from 0.6 to 300 times the "background" value. However, the high $\mathrm{CH}_{4}$ concentrations in the years 2013 and 2015 may be explained by the fact that part of the sewage sludge had been stored on a prism adjacent to the TSTS building.

The ratio of the concentration of biological agents measured near the TSTS divided by the "background" concentration was below 0.5 (with the exception of fungi). This suggests that neither the system associated with drying treated sludge nor the temporary storage of sludge posed a biological threat.

Additional measurements were made of biological and physical factors in April and June 2016. These measurements confirmed the limited impact of the analyzed TSTS on air quality. The total number of bacteria in the vicinity of the TSTS building did not exceed $1000 \mathrm{CFU} / \mathrm{m}^{3}$, and the total amounts of fungi amounted to $3300 \mathrm{CFU} / \mathrm{m}^{3}$. These values are higher than in other examined WWTP (Niazi et al. 2015). Within the TSTS building, the numbers were $1500 \mathrm{CFU} / \mathrm{m}^{3}$ and $1200 \mathrm{CFU} / \mathrm{m}^{3}$, for bacteria and fungi, respectively. Physical factors inside the building and in its near vicinity, such as dusts and thermal energy, were also investigated. With one technological line working, the number of dust particles in $1 \mathrm{dm}^{3}$ of air ranged from about 23,000 to 135,000 , while with two technological lines it ranged from about 55,000 to 276,000 (about twice as much as for one line). Thermal factors seemed to have a significant impact on the personnel operating the system. Thermal energy resulting from technological processes penetrated into the rooms of the building. The energy reached about $7.6 \%$ of the power of fluidized-bed furnaces (GOŚ-ŁAM corporate materials) and caused air temperatures in the tallest part of the building in excess of $37^{\circ} \mathrm{C}$. These are unfavorable and potentially hazardous working conditions.

Although an important environmental consideration, the levels of heavy metals (Gerstle and Albrinck 2012) and dioxins (Wang et al. 2012) emitted from the TSTS were not investigated in our study. The scientific literature does not confirm that the emission of heavy metals and dioxins from
TSTS poses a health risk to either personnel (Carmen et al. 2003; Shih et al. 2006) or the local population.

\section{Conclusions}

It is essential to monitor the emission of pollution from thermal sludge treatment systems. Analyzing technological processes in terms of emissions enables swift action to be taken if the concentration of pollutants exceeds established limits (Wielgosiński et al. 2016). This study, carried out in the case of the Group Sewage Treatment Plant of Lodz (GOŚ ŁAM) in Poland, has considered the impact of thermal treatment of digested and dewatered sludge on air quality in the vicinity of a wastewater treatment plant. The operation of the thermal sludge treatment system was found to have a negligible influence on the concentrations of chemical and biological pollutants in the air. The concentrations of chemical substances associated with the operation of the thermal sludge treatment system did not exceed $1 \%$ of the maximum allowable average annual value $\left(\mathrm{NO}_{\mathrm{x}}, \mathrm{PM}_{10}\right.$, and $\left.\mathrm{HCl}\right)$. This figure was slightly higher only in the case of $\mathrm{SO}_{2}$, which reached $4 \%$ of the maximum allowable average annual concentration. Experimental measurements revealed the concentrations of $\mathrm{H}_{2} \mathrm{~S}, \mathrm{SO}_{2}$, and $\mathrm{NO}_{\mathrm{x}}$ in the vicinity of the thermal sludge treatment system to be close to the "background" values. Much lower levels of bacteria and actinomycetes were observed than in other WWTP locations which have been studied. However, the concentrations of $\mathrm{CO}_{2}, \mathrm{NH}_{3}$, and $\mathrm{CH}_{4}$, as well as the number of colonies of fungi, were much higher than in the "background", and varied depending on the measurement data. The variability of these values over time was possibly due to the influence of other technological units in the WWTP.

Open Access This article is distributed under the terms of the Creative Commons Attribution 4.0 International License (http://creativeco mmons.org/licenses/by/4.0/), which permits unrestricted use, distribution, and reproduction in any medium, provided you give appropriate credit to the original author(s) and the source, provide a link to the Creative Commons license, and indicate if changes were made.

\section{References}

Arthurson V (2008) Proper sanitization of sewage sludge: a critical issue for a sustainable society. Appl Environ Microbiol 74(17):5267-5275. https://doi.org/10.1128/AEM.00438-08

Bianchini A, Bonfiglioli L, Pellegrini M, Saccani C (2015) Sewage sludge drying process integration with a waste-to-energy power plant. Waste Manage 42:159-165. https://doi.org/10.1016/j. wasman.2015.04.020

Carmen AM, Domingoa AI, Domingoa H, Corbela J (2003) Monitoring internal exposure to metals and organic substances in workers 
at a hazardous waste incinerator after 3 years of operation. Toxicol Lett 146(1):83-91. https://doi.org/10.1016/j.toxlet.2003.09.003

Cichowicz R (2018) Spatial distribution of pollutants in the area of the former CHP plant. E3S Web Conf 28:01007. https://doi. org/10.1051/e3sconf/20182801007

Cichowicz R, Stelęgowski A (2018a) The PMV and PPD indices in the selected boiler room. E3S Web Conf 44:00021. https://doi. org/10.1051/e3sconf/20184400021

Cichowicz R, Stelęgowski A (2018b) The distribution of air temperature and velocity in the selected boiler room. E3S Web Conf 44:00020. https://doi.org/10.1051/e3sconf/20184400020

Cichowicz R, Wielgosiński G, Targaszewska A (2016) Analysis of $\mathrm{CO}_{2}$ concentration distribution inside and outside small boiler plants. Ecol Chem Eng S 23(1):49-60. https://doi.org/10.1515/ eces-2016-0003

Cichowicz R, Wielgosiński G, Fetter W (2017) Dispersion of atmospheric air pollution in summer and winter season. Environ Monit Assess 189:605. https://doi.org/10.1007/s10661-017-6319-2

Dai J, Xu M, Chen J, Yang X, Ke Z (2007) PCDD/F, PAH and heavy metals in the sewage sludge from six wastewater treatment plants in Beijing, China. Chemosphere 66:353-361. https://doi. org/10.1016/j.chemosphere.2006.04.072

Ding W, Li L, Liu J (2015) Investigation of the effects of temperature and sludge characteristics on odors and VOC emissions during the drying process of sewage sludge. Water Sci Technol 72(4):543552. https://doi.org/10.2166/wst.2015.246

Directive 2008/50/EC of the European parliament and of the council of 21 May 2008 on ambient air quality and cleaner air for Europe, OJ L 152: 1-44. https://eur-lex.europa.eu/legal-content/ EN/ALL/?uri=CELEX\%3A32008L0050

Directive 2010/75/EU of the European parliament and of the council of 24 November 2010 on industrial emissions (integrated pollution prevention and control), OJ L 334:17-119. https://eur-lex. europa.eu/legal-content/EN/TXT/?uri=CELEX\%3A32010L0075

Fytili D, Zabaniotou A (2008) Utilization of sewage sludge in EU application of old and new methods - A review. Renew Sust Energ Rev 12:116-140. https://doi.org/10.1016/j.rser.2006.05.014

Gerstle RW, Albrinck DN (2012) Atmospheric emissions of metals from sewage sludge incineration. J Air Pollut Control Assoc 32(11):1119-1123. https://doi.org/10.1080/00022470.1982.10465 519

Horodecka N, Helbig A (2014) Annual assessment of the impact of equipment and technological processes of the group sewage treatment plant in Łódź on the state of ambient air pollution. Annual report for 2013, SGS Eko-Projekt Sp. z o.o., Pszczyna

Lu S, Yang L, Zhou F, Wang F, Yan J, Li X, Chi Y, Cen K (2013) Atmospheric emission characterization of a novel sludge drying and co-combustion system. J Environ Sci 25(10):2088-2092. https ://doi.org/10.1016/S1001-0742(12)60272-1

Niazi S, Hassanvand MS, Mahvi AH, Nabizadeh R, Alimohammadi M, Nabavi S, Faridi S, Dehghani A, Hoseini M, Moradi-Joo M, Mokamel A, Kashani H, Yarali N, Yunesian M (2015) Assessment of bioaerosol contamination (bacteria and fungi) in the largest urban wastewater treatment plant in the Middle East. Environ Sci Pollut Res 22(20):16014-16021. https://doi.org/10.1007/s1135 6-015-4793-Z

Pająk T (2013) Thermal treatment as sustainable sewage sludge management. Environ Prot Eng 39(2):41-53. https://doi.org/10.5277/ EPE130205

Panepinto D, Genon G (2014) Wastewater sewage sludge: the thermal treatment solution. WIT Trans Ecol Environ 180:201-212. https ://doi.org/10.2495/WM140171
Pohorely M, Svoboda K, Trnka O, Baxter D, Hartman M (2005) Gaseous Emissions from the Fluidized-Bed Incineration of Sewage Sludge. Chem Pap 59(6b):458-463

Procyk G, Helbig A (2013) Annual assessment of the impact of equipment and technological processes of the Group Sewage treatment plant in Łódź on the state of ambient air pollution. Annual report for 2012, SGS Eko-Projekt Sp. z o.o., Pszczyna

SGS Eko-Projekt (2015) Annual assessment of the impact of equipment and technological processes of the group sewage treatment plant in Łódź on the state of ambient air pollution. Annual report for 2014, SGS Eko-Projekt Sp. z o.o., Pszczyna

Shah RK, Thonon B, Benforado DM (1999) Opportunities for heat exchanger applications in environmental systems. In: Bejan A, Vadász P, Kröger DG (eds) Energy and the environment. Kluwer Academic Publishers, Dordrecht, pp 49-64

Shih TS, Chen HL, Wu YL, Lin YC, Lee CC (2006) Exposure assessment of polychlorinated dibenzo-p-dioxins and dibenzofurans (PCDD/Fs) in temporary municipal-waste-incinerator maintenance workers before and after annual maintenance. Chemosphere 64(9):1444-1449. https://doi.org/10.1016/j.chemospher e.2006.01.014

Skwarska A, Horodecka N (2016) Annual assessment of the impact of equipment and technological processes of the Group Sewage Treatment Plant in Łódź on the state of ambient air pollution. Annual report for 2015, SGS Eko-Projekt Sp. z o.o., Pszczyna

Strauch D (1991) Microbiological treatment of municipal sewage sludge and refuse as means of disinfection prior to recycling in agriculture. Stud Environ Sci 42:121-136. https://doi.org/10.1016/ S0166-1116(08)70320-0

Svoboda K, Hartman M, Šyc M, Pohořelý M, Kameníková P, Jeremiáš M, Durda T (2016) Possibilities of mercury removal in the dry flue gas cleaning lines of solid waste incineration units. J Environ Manage 166:499-511. https://doi.org/10.1016/j.jenvm an.2015.11.001

Wang C, Yu Q, Sheng S, Gao Z, Wu C, Wang K (2012) The performance and environmental impact of the integrated spray drying and incineration demonstration project for dying sludge treatment. Procedia Environmental Sciences 16:433-442. https://doi. org/10.1016/j.proenv.2012.10.060

Werther J, Ogada T (1999) Sewage sludge combustion. Prog Energy Combust Sci 25:55-116. https://doi.org/10.1016/S0360 -1285(98)00020-3

Werther J, Ogada T, Philippek C (1995) Sewage sludge combustion in the fluidized bed comparison of stationary and circulating fluidized bed techniques. Proc Int Conf Fluidized Bed Combust 2:951-962

Wielgosiński G (2016) Thermal treatment of municipal wasteselected issues (Termiczne przekształcanie odpadów komunalnych—wybrane zagadnienia), Nowa Energia, Racibórz. https:// nowaenergia.com.pl/wydawnictwa-ksiazkowe

Wielgosiński G, Wiśniewski J, Targaszewska A, Łechtańska P (2014) Analysis of the functioning of the drying sewage sludge system in GOŚ- $-\mathrm{AM}$ in lodz, inżynieria i ochrona. Środowiska 17(3):459-471

Wielgosiński G, Cichowicz R, Wiśniewski J (2016) Ammonia emission from sewage sludge incineration process. Ecol Chem Eng $\mathrm{S}$ 23(4):665-675. https://doi.org/10.1515/eces-2016-0047 